\title{
Human Resource Management and Employee Performance in Federal University of Technology Akure
}

\author{
Onafadeji Adeniyi $\mathrm{O}^{1}$, Ogunyemi Festus $\mathrm{F}^{2}$, AlarapeBabatunde $\mathrm{A}^{3}$ \\ ${ }^{1} \& 2$ Department of Business Administration, School of Management Technology, Federal University of \\ Technology, Akure Nigeria \\ ${ }^{3}$ Department of Project Management Technology, School of Management Technology, Federal University of \\ Technology, Akure Nigeria
}

\begin{abstract}
The study on human resources and the performance of employees in an organization have taken different faces of attention amidst various scholars and professionals in recent past, but this study dwells on the effectiveness of human resources in achieving a better employee performance. Based on this premise, the study examined the effectiveness of human resource management in achieving employee performance in The Federal University of Technology, Akure. The study examines effectiveness of training and development in enhance employee skills, knowledge and attitude to work and evaluate effect of promotion exercise on labour turnover. Survey method was adopted in gathering data and the data collected were carefully analysed using descriptive statistics such as frequency distribution, percentages, mean, standard deviation, relative importance index and chi-square in testing of the research hypotheses. The study shows that there is a significant relationship between human resource management and employee performance as all tends to have a significant effect on each other. The study concludes that training and development of staff should be a routine activity irrespective of the cadre, and promotion exercise is free from biased. The study therefore recommends that effective training and development, and promotion exercise truly enhance employee performance.
\end{abstract}

Keywords:Employee Performance,Human Resource Management, labour turnover, Training and Development, Promotion Exercise.

\section{Introduction}

One area of an organizational performance is the management of workers in an organization. An organization basically in both private and public sector depends on certain resources such as men, material, money, machine and information resources. It is through the combination of these resources that the attainment of an employee performance can be achieved. However the most significant and complex component for the attainment of performance in an organization is the human resource.[1] opined that "human resource is primarily concerned with how people are managed within organizations, focusing on policies and systems". Human resource departments and units in organizations are typically responsible for a number of activities, including employee recruitment, training and development, performance appraisal and rewarding (e.g., managing pay and benefit systems). [2], also define human resources management as "the process of analyzing and managing an organization's human resource needs to ensure satisfaction of its strategic objectives". Which implies that an organization can achieved its stated objectives and goals if and only if the human resources are analyzed and manage effectively. [3]in his own view sees human resource management as the policies and practices involved in carrying out the people or human resources aspects of a management position including recruitment, screening, training and appraising.

Human resource composed of individual working for an organization, employed these days as permanent staff, temporary staff, or contracted staff but collectively making up the most important aspect of organizational resources. Therefore, an organization must have the right number and types of employees who must be managed in such a way that they will be able to achieve their personal objectives and organizational performance. Since the early 1980s, the field of human resources management has been in a state of rapid transition. As the world continues to experience profound changes, different sets of changes are revolving. Today, most managers are comfortable with the term "Human Resources" but a few still prefer to refer employee as "personnel".[4] concur at one level that terminology may be deemed to be less important, because it is practice that really counts. However, at another level he argues that it's also of importance in the sense that ways of managing people at work have come a long way in the last fifteen years, and a refusal to use the modern term "human resources" can be an indication of a failure to recognize and utilize recent development. Therefore, for an organization to achieved its objective effectively and efficiently, human resources which is viewed as the most active agent of all its resources must be given due recognition. Employee performance plays an important role for both an employee and the organization at large. [5]is of the opinion that employee performance is looked at in terms of outcome and behavior of an employee. Hence, employee performance is what an employee 
does or does not do. Against this background, the study tends to examine the effectiveness of human resources in achieving employee performance.

The primary purpose of any organization is to accomplish goals and objectives and since the degree of accomplishment depends totally on the quality of its members of staff therefore, it involves the availability and improvement of human resources. To this end, for an organization to achieved adequate performance, it must ensure adequate supply of human skills. Following the growing technological changes and complexity in various organizations as well as social factors, it then becomes necessary that organizations should train and develop their personnel to cope with ever increasing job requirements posed by fast technological and social changes.

From an organizational perspective, most organization do not make adequate provision for training of their employee and also do not send workers for the right kind of training programme to enhance their work productivity [6]. Studies conducted by [7], shows that most workers are not being promoted from their previous status which is an indication of poor motivation for workers and this influences their level of job performance/productivity. Also, the recruitment of unskilled personnel often lead to high turnover [8].

Studies on training and development, promotion exercise in achieving employee performance are no longer new in the field of human resource management but in spite of the attention, it continues to generate extreme dissatisfaction for employees' performance. In other words, limited studies have been carried out regarding the effectiveness of human resource management in achieving employee performance in an educational sector. Evidently, a gap exists in the literature regarding training and development, promotion exercise in achieving employee performance in FUTA which this study tends to fill. Hence, this study examined the effectiveness of human resource management in achieving employee performance with a special reference to FUTA.

The aim of this study was to examine the effectiveness of human resource management in achieving employee performance while the specific objectives are to;

(i) examine the effectiveness of training and development in enhancing employee skills, knowledge and attitude to work in FUTA and;

(ii) evaluatethe effect of promotion exercise on labour turnover in FUTA.

1.1 Research Hypotheses

$\mathbf{H}_{\mathbf{0}}$ : effective training and development has no significant effect on employee skills, knowledge and attitude.

$\mathbf{H}_{0}$ : Promotion exercise has no significant effect on labour turnover.

\subsection{Conceptof Human Resource Management}

\section{Literature Review}

There are numerous definitions of the term human resource management as there are many experts in the field and it is called by different terminology for example, in certain public enterprises it may be called personnel administration, employee relations or manpower.

[9]assert that different terms are used in describing human resource management and they include 'labour management', 'labour administration', 'labour-management relations', 'personnel administration', 'personnel management', 'human capital management', 'human asset management' and the likes.

Northcott, (2007) as cited in [10] considers human resource management as an extension of general management, that of prompting and stimulating every employee to make his fullest contribution to the purpose of a business. He stressed further that human resource management is not something that could be separated from the basic managerial function, it is a major component of the broader managerial function. [11]were of the opinion that human resource management is that part of management that is designed to provide for and coordinate the employees in the organization. Plants, equipment and all others that a modern firm uses are unproductive except for the effort and direction of human resource. [5]defineshuman resource management as the strategic and coherent approach to the management of an organization's most valued assets; the people working there who individually and collectively contribute to the achievement of the objectives of the organization. According to [12] human resource management is that part of management which is concerned with people at work and with their relationship within an enterprises and it seeks to achieve both efficiency and justice. [13] opined that human resource management is that part of management process that specializes in the management of people in the work organization. [14]defines human resource management as the recruitment, selection, development, utilisation, compensation and motivation of human resources (that is people) by the organisation.

In summary, from the various meaning and definition cited by eminent scholars about the concept human resource management, one can deduce that although the statement are different but there is a common trend running through them. The common trend linking these definitions, therefore, is the fact that HRM as it is popularly called is the use of various activities, management of people at work, philosophy, policies, procedures and practices related to the management of people,organization's most valued assets, skills, talents and 
knowledge of people. Human resource management therefore may be defined as an effective and efficient utilization of productive resources at work.

\subsubsection{Conceptof Employee performance}

In an organizational concept, performance is usually defined as the extent to which an organizational member (employee) contributes to achieving the goals of the organization. Employee performance plays an important role for an organizational performance. Hence, employee performance is originally what an employee does or does not do. [5] is of the opinion that employee performance is normally looked at in terms of outcomes. However, he stated further by saying it can also be looked at in terms of behaviour.[15] noted that performance of an employee include: quality of output, quantity of output, timeliness of output, presence at work and cooperativeness. In conclusion, employee performance could be simply understood as the related activities expected of an employee and how well the activities are executed.

\subsubsection{Training and Development}

[16] is of the opinion that organizational growth is closely related to the development of its human resources when employees fail to grow and develop in their work, stagnant organization most likely will result. A strong employee training and development programme does not guarantee organizational success, but such a programme is generally found to be successful.

The heart of the development process in most organizations is composed of on the job and off the job activities that teaches employees new skills and abilities. Because modern managers recognize the benefit derived from the training and development process, expenditures for employee education are at an all-time high. The rise in employee education has been accompanied by growing professionalism in the training field and a demand for competent, quality trainers.

[17]concur that the right employee training, development and education at the right time, provides big payoffs for the organization in increase productivity, knowledge, loyalty and contribution. Also [18] assert that training and development is a process that attempts to provide employees with information, skills and understanding of the organization and its goals. Additionally training and development aids an employee to continue to make the necessary positive contribution to the success of employing organization in terms of his / her good performance on the job.

[19] assert that training and development are indispensable strategic tools for effective individual and organisation performance, thus, organisation are spending money on it with confidence that it will earn them a competitive advantage in the world of business. However, for any organisation to achieve its stated goals and objective in this competitive world, adequate and relevance training and development of staff cannot be over emphasized.

[19] in their study which was carried out among members of some selected banks in Lagos State, South-West Nigeria shows that induction and orientation is effective in equipping employees with the practice and core value of the organisation and what is expected of them to do. In addition, mentoring, coaching, job rotation as an element of training and development enhance employee performance. Therefore, it was concluded that behavioural training techniques have a significant effect on employee performance and organizational effectiveness.

Similarly, in a framework carried out by [20] on employee development and its effect on employee performance, he opined that employee development means to develop the abilities of an individual employee and organization as a whole. Hence employee development consists of development of individual or employee and overall growth of the employee of an organization. Therefore, there is a direct relationship between employee development and employee performance. [20]opined that as well as when employees would be more developed, they would be more satisfied with their job, more committed with their job and their performance would increase and when employee performance increases, this will lead to the organization effectiveness. He formulated a model which explains the relationship between employee development and employee performance. Employee performance as a variable depend on employee development. Employee development variable is operationalized by the following sub variables: employee learning, skill growth, self-directed, employee attitude and behaviour which will automatically lead to organizational effectiveness. The study concluded that development of an employee will result to an employee performance and which will automatically lead to the effectiveness of an organization.

Similarly in a study carried out by [21] on "Modelling the Relationship between Motivating Factors; Employee' Retention; and Job Satisfaction in the Nigerian Banking Industry in which one of the main objective of the study was to examine the correlation between promotion and fringe benefits towards theretention of staff in the banking industries. The study was conducted in Abeokuta Ogun State Nigeria among 10 financial institution and the findings indicate that the effect of promotion on employee retention is positive with the regression weight of $.185(\mathrm{p}<0.001)$. When promotion goes up by 1 standard deviation, employee retention goes up by 0.185 standard deviations. 
As one would have expected, promotion tends to serve as a motivating factor for employees to remain on their jobs for a long period of time. This could be accepted because when employees look forward for their promotion and they get it as at when due, it then creates an enabling environment for better performance. This study suggested that decision makers should incorporate these variables (salary and promotion) into their employment relations strategies. [21]

\subsection{Theoretical Framework}

Themotivational theory adopted for this study and has been explained by [22]includes the Abraham Maslow's Hierarchy of Needs, Alderfer's ERG theory, and Herzberg's Movitator-Hygeine theory. To this could be added McGregor X and Y theory as opined by Armstrong 2002. Abraham Maslow's and McGregor theory discussed about self-actualising workers. According to Maslow, the needs that people are motivated to satisfy falls into a hierarchy.Physiological (food, water, and sex), safety (security) and social (friendship) needs are at the bottom while the self-esteemed and self-actualisation needs are at the top. In general, the Abraham Maslow lower needs must be satisfied before higher level needs must be met.

Alderfer's ERG theory work on Maslow's hierarchy needs theory by reducing them to three: existence [E], relatedness [R] and growth [G] (Porter et al., 2003). However the two theories could be said to be analogous; existence relates to survival and safety; relatedness to belonging and self-esteem (and ego); and growth to the development of human potential as in self-actualisation [23]. Where Alderfer did add to Maslow was in the recognition that not only was there a satisfaction/progression relationship, there was also one of frustration/regression. This could mean, for instance, that an employee could reach a sense of high self-esteem, lose their job and regress to survival mode, in other words, one state does not necessary lead to another, the element of the hierarchy can change, retrench, regress, and also co-exist [22].

Herzberg's Motivation-Hygiene theory, also called the Two-factor theory, looked at employees' levels of job satisfaction within an organisation, or more precisely the nature of the work itself and how it has the potential for arousing both satisfaction and dissatisfaction. Motivators arousing satisfaction include factors such as achievement, recognition and responsibility. Discrepancies in motivators, which led to employee discontent, or hygiene factors as Herzberg termed them, could include things such as company policy, salary, managerial style, and relations with work colleagues [22].

McGregor distinguished two alternative basic assumptions about workers and their approaches to work in an organization. The two assumption which he called Theory X and Y, takes opposite views of people's commitment to work in organizations. Theory $\mathrm{X}$ assumes that workers must be coaxed and force into putting forth effort in their jobs while, Theory $\mathrm{Y}$ on the other hand, assume that workers relish work and eagerly approach their work as an opportunity to develop their creative capacities. The root of Theory X can be traced to the days of scientific management while Theory $\mathrm{Y}$ was an example of complex person perspective[22].

\section{Methodology}

The study was carried out in The Federal University of Technology Akure, Nigeria between the Teaching and Non-Teaching staff. The method used in this study is the survey type which involves the selection and studying the sample chosen from the population in order to examine the effectiveness of human resource management in achieving employee performance in The Federal University of Technology Akure. The sample size was 340 members of staff which was selected from the total population of 2,191 from both the teaching and non-teaching staff based on a simplified formulaof determining sample size for research activity [24]. A proportion of $60 \%$ to $40 \%$ was used in selecting the respondentsusing the purposive samplingtechnique since the non-teaching staff are more than the teaching staff. Questionnaires was used as research instrument for the study.

In addition, the questions was divided into three sections; the first section contains demographic information of the respondents, such as Age, Sex, Marital status, Educational Status among others. Second session deals with questions pertaining to effectiveness of training and development in enhancing employee skills, knowledge and attitude to work; while the last section as well deals with questions on effect of promotion exercise on labour turnover. Analysis of data was done using the descriptive statistics and inferential. The formal include frequency distribution, percentages and relative importance index, mean and standard deviation while the later include Chi-Square which was used in testing of hypotheses.

\section{Results And Discussion}

This section presents the results and discussion of the study on the effectiveness of human resource management and employee performance with reference to FUTA. Three-hundred and forty questionnaire (340) were administered for the purpose of the study using simple random sampling technique in the proportion of two-hundred and four (204) and one-hundred and thirty six (136) to both teaching staff and non-teaching staff respectively. The total number of questionnaire returned for the analysis were three-hundred and twelve (312), representing $91.8 \%$ response. 


\subsection{Social-Demographic Profile of the Respondents}

The results of the study as presented in table 1 shows that the male respondents accounted for the largest population of respondents used for this research, representing $67.3 \%$ of the total sample used for the study, while female can only account for only $32.7 \%$. This implies that there are more male staff of FUTA than female staff. Age distribution indicates that the larger number of respondents belong to the age bracket of 26 35 years which accounted for $44.6 \%$. Further, it is evident that significant percentage of the respondents are married at the time of this survey, which represents $82.05 \%$, while insignificant percentage are single, representing $17.95 \%$ of the respondents. In addition, respondents with Post Graduate qualification accounted for highest frequency (178) with $57.1 \%$, followed by B.Sc/B.A/B.Tech/HND (95) with 30.4\%, OND/NCE and SSCE (36 and 3) with $11.5 \%$ and $1.0 \%$ respectively. Another demographic characteristic is the respondents work experience which indicates that majority of the respondents with a frequency of $148(47.4 \%)$ have been a staff of the institution for a period less than 10 years whilst $67(21.5 \%)$ of them have spent $10-15$ years as a staff of FUTA. Moreover, 41 (13.1\%) of the respondents have been for a period between $16-20$ years while 34 $(10.9 \%)$ and $22(7.1 \%)$ have spent $21-25$ years and above 25 years respectively. Category of staff indicate that $58.7 \%$ of the respondents were non-teaching staff while the remaining $41.3 \%$ accounted for the teaching staff. Also from the grade level of respondents, it is obvious that Junior Staff make up the largest portion of respondents for this research with $26.9 \%$, GA-AL were next with $24.0 \%$, followed by senior staff accounting for $22.8 \%$, LII-LI represent $20.5 \%$, SL-Prof accounted for the remaining $5.8 \%$ of the respondent. Lastly, majority of the respondents which accounted for $94.55 \%$ are permanent staff of FUTA while the remaining $5.45 \%$ are contract staff of the institution.

Table 1: Respondents Demographic Characteristic

\begin{tabular}{|c|c|c|}
\hline Respondent's Gender & Frequency & Percentage \\
\hline Male & 210 & 67.3 \\
\hline Female & 102 & 32.7 \\
\hline Total & 312 & 100.0 \\
\hline Ages of Respondents & Frequency & Percentage \\
\hline 18-25 Years & 2 & 0.6 \\
\hline 26-35 Years & 139 & 44.6 \\
\hline $36-45$ Years & 119 & 38.1 \\
\hline 46 and above & 52 & 16.7 \\
\hline Total & 312 & 100.0 \\
\hline Marital Status & Frequency & Percentage \\
\hline Single & 56 & 17.95 \\
\hline Married & 256 & 82.05 \\
\hline Total & 312 & 100.0 \\
\hline Educational Qualification & Frequency & Percentage \\
\hline SSCE & 3 & 1.0 \\
\hline OND/NCE & 36 & 11.5 \\
\hline B.Sc/B.A/B.Tech/HND & 95 & 30.4 \\
\hline Post Graduate & 178 & 57.1 \\
\hline Total & 312 & 100.0 \\
\hline Work Experience & Frequency & Percentage \\
\hline Less than 10 years & 148 & 47.4 \\
\hline $10-15$ years & 67 & 21.5 \\
\hline $16-20$ years & 41 & 13.1 \\
\hline $21-25$ years & 34 & 10.9 \\
\hline Above 25 years & 22 & 7.1 \\
\hline Total & 312 & 100.0 \\
\hline Categories of Staff & Frequency & Percent \\
\hline Non-Teaching Staff & 183 & 58.7 \\
\hline Teaching Staff & 129 & 41.3 \\
\hline Total & 312 & 100.0 \\
\hline Grade Level & Frequency & Percent \\
\hline Junior Staff & 84 & 26.9 \\
\hline Senior Staff & 71 & 22.8 \\
\hline GA-AL & 75 & 24.0 \\
\hline LII-LI & 64 & 20.5 \\
\hline SL-Prof & 18 & 5.8 \\
\hline Total & 312 & 100.0 \\
\hline Mode of Employment & Frequency & Percent \\
\hline Permanent & 295 & 94.55 \\
\hline Contract & 17 & 5.45 \\
\hline Temporary & - & - \\
\hline Total & 312 & 100.0 \\
\hline
\end{tabular}

Source: Author's Field Report, 2016 


\subsection{Effectiveness of Training and Development and Employee Performance.}

The results of the study as presented in table 2 shows that $56.1 \%$ of the respondents have not benefitted from training and development from the University while the remaining $43.9 \%$ have benefitted immensely from the University in terms of training and development. Meanwhile majority of the respondent $42.3 \%$ were selected for training and development upon joining the institution. Furthermore, 51.1\%, submitted that they are trained at an interval of 2 -years or more while $58.4 \%$ of sampled respondents agreed that the level of training /development acquired on their job performance in FUTA was effective. 35\% of the respondent strongly agree that it has a direct positive impact, $46.0 \%$ agreed with the assertion. Training is a very important part of the human resource development activity of human resource management practice and the finding reveals that it has more impact on the skills, knowledge and attitude of staffs towards work in FUTA. The implication of the results confirms that training adversely impacts on employee's work performance. The findings as well supported the study of [19] which concluded that behavioural training techniques has a significant effect on employee performance and organizational effectiveness and by so doing employee skills, knowledge and attitude will be harnessed. Also the findings supported a framework carried out by [20]which explain that there is a direct relationship between employee development and employee performance. This study concludes that development of an employee will result to an employee performance and which will automatically lead to an employee gaining more skills, knowledge in discharging of duties in an organization. The mean and standard deviation of the first research objectives is being explained in table 3 .

Table 2.Effectiveness of Training and Development on Employee Skills, knowledge and Attitude

\begin{tabular}{|c|c|c|c|}
\hline Beneficiary & Option & Frequency & Percentage \\
\hline & Yes & 137 & 43.9 \\
\hline & No & 175 & 56.1 \\
\hline & Total & 312 & $\mathbf{1 0 0 . 0}$ \\
\hline \multirow{7}{*}{$\begin{array}{l}\text { Mode of Selection of } \\
\text { T\&D }\end{array}$} & Option & Frequency & Percentage \\
\hline & On joining the University & 58 & 42.3 \\
\hline & Head of Unit/Department Recommendation & 35 & 25.5 \\
\hline & Compulsory for all staff & 6 & 4.4 \\
\hline & Upon staff request & 13 & 9.5 \\
\hline & Based on Performance & 25 & 18.2 \\
\hline & Total & 137 & 100.0 \\
\hline \multirow[t]{7}{*}{ Training Received } & Option & Frequency & Percentage \\
\hline & Quarterly & 2 & 1.5 \\
\hline & Bi-annual & 7 & 5.1 \\
\hline & Annually & 12 & 8.8 \\
\hline & 2- years interval or more & 70 & 51.1 \\
\hline & No specific period & 46 & 33.5 \\
\hline & Total & 137 & 100.0 \\
\hline \multirow{6}{*}{$\begin{array}{l}\text { Effect of T \& D on Job } \\
\text { Performance }\end{array}$} & Option & Frequency & Percentage \\
\hline & Very Effective & 48 & 35.0 \\
\hline & Effective & 80 & 58.4 \\
\hline & Not sure & 6 & 4.4 \\
\hline & Not effective & 3 & 2.2 \\
\hline & Total & 137 & 100.0 \\
\hline \multirow[t]{7}{*}{$\begin{array}{l}\text { Direct Impact of T \&D } \\
\text { on Skills, Knowledge } \\
\text { and Attitude of } \\
\text { Employee }\end{array}$} & Option & Frequency & Percentage \\
\hline & Strongly Agree & 48 & 35.0 \\
\hline & Agree & 63 & 46.0 \\
\hline & Undecided & 16 & 11.6 \\
\hline & Disagree & 7 & 5.2 \\
\hline & Strongly Disagree & 3 & 2.2 \\
\hline & Total & 137 & 100.0 \\
\hline
\end{tabular}

Source: Author's Field Report, 2016 
Table 3: Mean and Standard Deviation of effectiveness of Training and Development in enhancing Employee Skills, Knowledge and Attitude

\begin{tabular}{|l|l|l|}
\hline Items & Mean & Standard Deviation \\
\hline Beneficiary of training/ development from the University & 1.56 & 1.104672 \\
\hline Mode of Selection for the Training & 2.36 & 0.822815 \\
\hline Training Received & 4.10 & 0.47655 \\
\hline $\begin{array}{l}\text { Effect of Training and Development on your Job Performance in } \\
\text { FUTA }\end{array}$ & 3.26 & 1.281028 \\
\hline $\begin{array}{l}\text { Direct Impact of Training and Development on Skills, } \\
\text { Knowledge and Attitude of Workers in Discharging of Duty in } \\
\text { FUTA. }\end{array}$ & 4.07 & 1.282199 \\
\hline
\end{tabular}

\section{Source: Author's Field Report, 2016}

\subsection{Test of Research Hypotheses One}

Table 4 presents the statistical result of the Chi square test; to test the significant effect of effective training and development on employee skills, knowledge and attitude. The statistical results show that the estimated Chi-square statistical value of 86.238 is significant at the $95 \%$ level (i.e. Significant value, $p=0.004$ ) $<0.05$ ), in view of this, the null hypothesis, H0: Effective training and development has no significant effect on employee skills, knowledge and attitude, is rejected while the alternate hypothesis H1: Effective training and development have significant effect on employee skills, knowledge and attitude is accepted. This findings is in consonance with [17] who concur that the right employee training, development and education at the right time, provides big payoffs for the organization in increase productivity, knowledge, loyalty and contribution.

Also [18], concur that training and development is a process that attempts to provide employees with information, skills and understanding of the organization and its goals. Additionally training and development aids an employee to continue to make the necessary positive contribution to the success of employing organization in terms of his / her good performance on the job. Hence the hypothesis that "effective training and development have significant effect on employee skills, knowledge and attitude" is accepted.

Table 4: Test of Research Hypotheses

\begin{tabular}{|l|l|}
\hline \multicolumn{2}{|c|}{ Chi Square Test Statistics } \\
\hline & $\begin{array}{l}\text { Effective training and development have no significant effect on employee skills, } \\
\text { knowledge and attitude. }\end{array}$ \\
\hline Pearson Chi-Square & 86.238 \\
\hline Df & 1 \\
\hline Sig. value (p) & .004 \\
\hline
\end{tabular}

Source: Author's Field Report, 2016

\subsection{Effectiveness of Promotion Exercise on Labour Turnover}

Table 5 explain the effect of promotion exercise on labour turnover and it reveals that $80.8 \%$ of the respondents have been promoted from one level to another, while the remaining $19.2 \%$ of the respondent have not benefitted from any promotion exercise. The result indicate that majority of the staff have been promoted from one level to another. Meanwhile, $36.1 \%$ of the respondents concur that promotion exercise is very good while a larger proportion of the respondents $(50 \%)$ also concluded that the exercise is good. $11.1 \%$ of the respondents sees the promotion exercise in FUTA has been fair while a cumulative percentage of $2.8 \%$ concluded that the promotion exercise in FUTA is poor and very poor respectively. Furthermore, one hundred and forty-one respondents (141) representing 56\% strongly agreed that the promotion exercise was relevant in enhancing their job performance in FUTA. Seventy-eight (78) respondents agreed that promotion exercise enhances their job performance, 13 respondents remained undecided as whether it has a positive effect on their job performance. Moreover, 12 respondents disagree with promotion exercise being a job performance enhancement strategy and 8 respondents also strongly disagreed likewise. The findings indicate that truly promotion exercise enhance performance in an organization. Also, majority of the respondents (47.2\%) agreed to the effectiveness of promotion exercise on workers turnover, while $35.3 \%$ of the respondent strongly agreed as well. Meanwhile, 4\% were undecided as whether promotion exercise has a significant effect on labour turnover while a cumulative percentage of $13.5 \%$ disagreed and strongly disagreed respectively. This results indicate that promotion exercise has a strong significant effect on labour turnover that is when promotion is received as at when due, workers would find it difficult to leave their present organization for another organization. The findings also supported the view of [21] on their study "Modelling the Relationship between Motivating Factors; Employee' Retention; and Job Satisfaction in the Nigerian Banking Industry in which one of the main objective of the study was to examine the correlation between promotion and fringe benefits towards theretention of staff in the banking industries. As one would have expected, promotion tends to serve as a motivating factor for employees' performance and to remain on their jobs for a long period of time. This could 
be accepted because when employees look forward for their promotion and they get it as at when due, it then creates an enabling environment for better performance. Therefore, promotion exercise has a significant effect on labours turnover. The mean and standard deviation of the effect of promotion exercise on labour turnover is explained in table 6 . 
Human Resource Management and Employee Performance in Federal University of Technology

Table 5: Effectiveness of Promotion Exercise on Labour Turnover

\begin{tabular}{|c|c|c|c|}
\hline Effect of Promotion Exercise in FUTA & Option & Frequency & Percentage \\
\hline & Yes & 252 & 80.8 \\
\hline & No & 60 & 19.2 \\
\hline & Total & 312 & 100.0 \\
\hline \multirow[t]{7}{*}{ Assessment of Promotion Exercise so far in FUTA } & Option & Frequency & Percentage \\
\hline & Very Good & 91 & 36.1 \\
\hline & Good & 126 & 50.0 \\
\hline & Fair & 28 & 11.1 \\
\hline & Poor & 5 & 2.0 \\
\hline & Very Poor & 2 & 0.8 \\
\hline & Total & 252 & 100.0 \\
\hline \multirow{7}{*}{$\begin{array}{l}\text { Positive Effect of Promotion Exercise on Job } \\
\text { Performance in FUTA }\end{array}$} & Option & Frequency & Percentage \\
\hline & Strongly Agree & 141 & 56.0 \\
\hline & Agree & 78 & 31.0 \\
\hline & Undecided & 13 & 5.1 \\
\hline & Disagree & 12 & 4.8 \\
\hline & Strongly Disagree & 8 & 3.1 \\
\hline & Total & 252 & 100.0 \\
\hline \multirow{7}{*}{$\begin{array}{l}\text { Significant Effect of Promotion Exercise on Workers } \\
\text { Turnover in FUTA }\end{array}$} & Option & Frequency & Percentage \\
\hline & Strongly Agree & 89 & 35.3 \\
\hline & Agree & 119 & 47.2 \\
\hline & Undecided & 10 & 4.0 \\
\hline & Disagree & 23 & 9.1 \\
\hline & Strongly Disagree & 11 & 4.4 \\
\hline & Total & 252 & 100.0 \\
\hline
\end{tabular}

Source: Author's Field Report, 2016

Table 6: Mean and Standard Deviation of Effect of Promotion Exercise on Labour Turnover.

\begin{tabular}{|l|l|l|}
\hline Items & Mean & Standard Deviation \\
\hline Responses on the Effect of Promotion Exercise in FUTA. & 1.19 & 1.495783 \\
\hline Assessment of Promotion Exercise so far in FUTA & 4.19 & 0.160935 \\
\hline Positive Effect of Promotion Exercise on Job Performance in FUTA & 4.32 & 1.722179 \\
\hline The Significant Effect of Promotion Exercise on Workers Turnover in FUTA & 4.00 & 1.679891 \\
\hline
\end{tabular}

\section{Source: Author's Field Report, 2016}

\subsection{Test of Research Hypotheses Two}

Table 7 presents the hypothesis testing for the second hypothesis which is to ascertain the significant effect of promotion exercise on labour turnover or whether the effect should be disregarded. The Chi-square test of 9.315 is significant at $95 \%$ level (i.e. Significant value, $\mathrm{p}=0.001<0.05$ ), in view of this, the null hypothesis, $\mathrm{H}_{0}$ : effect of promotion exercise has no significant effect on labour turnover, is rejected while the alternate hypothesis, $\mathrm{H}_{1}$ : Effective promotion exercise have a significant effect on labour turnover, is accepted. This study is in accordance with the opinion of [21] who assert that as one would have expected, promotion tends to serve as a motivating factor for employees to remain on their jobs for a long period of time and the absence of promotion exercise would cause talented employees to quit the organization and if there is a high ratio of labour turnover the growth of such organization tends to decreased. Therefore, the hypothesis that effective promotion exercise have a significant effect on labour turnover, is accepted.

Table 7: Chi Square Test Statistics

\begin{tabular}{|l|l|}
\hline \multicolumn{2}{|c|}{ Table 7: Chi Square Test Statistics } \\
\cline { 2 - 3 } & Effective promotion exercise has no significant effect on labour turnover \\
\hline Df & 9.315 \\
\hline Sig. value (p) & .001 \\
\hline
\end{tabular}

Source: Author's Field Report, 2016 


\section{Conclusion}

The study examine the effectiveness of human resource management in achieving employee performance in FUTA. It found out that human resources unit as a pivotal unit in facilitating competitive advantage should laid more emphasis on training and development of staffs, also training and development should be a kind of routine activities for staffs irrespective of their cadre be it a junior staff or a senior staff and as a result, the best potential (skills, knowledge and attitude) in them would be identify to achieve better performance. The study also conclude that promotion exercise of staffs is free from biased and it goes a long way in bringing out the best out of them. When a staff is being promoted as at when due better performance would be achieved and this drastically reduce labour turnover.

\subsection{Recommendation}

From the result of the study conducted, it was discovered that human resource department has a lot of impact on the employee and the organisation at large. This is because it regulates the activities of the organisation in order to implement an effective policy on the employees. Based on the findings, the study recommends that management should put more effort in training of staff by sending them for workshops and conferences so that the largest percentage $(56.1 \%)$ who have not benefitted any training from the University may benefit as well and as a result, their skill, knowledge and attitude would be harnessed. Also management should ensure that staff are promoted as at when due so that the remaining (7.9\%) who felt the promotion exercised does not have a significant effect on labour turnover can as well be promoted as at when due.

\section{References}

[1]. Johnson, P. HRM in changing organizational contexts (D. G. Collings, \& G. Wood, Eds, London: Routledge, 2009).

[2]. Hellrigel, D., Jackson, S., Slocum, J., \& Staude, G. Management (3rd ed. Australia: Pearson, 2009).

[3]. Dessler, G. Human resource management theory, skills and aplication (3rd ed. Australia: Pearson, 2007).

[4]. Allan, C. Managing human resources (3rd ed. London: Routledge Publisher, 1998).

[5]. Armstrong, M. Employee reward (3rd ed. Wimbedon London: Chartered Institute of Personnel Management and Development, 2002).

[6]. Boxall, P., Purcell, J., \& Wright, P. The oxford of human resource management (Britain: oxford university press Brodie, 2007).

[7]. Champoux, J. E. Organizational behaviour: Essential tenents for a new millennium (London: South Western College Publishing, 2000).

[8]. Jehanzeb, K., \& Alkelabi, S. A. Role of learning theories in training while training the trainers, International Journal of Academic Research in Business and Social Sciences, 2(11), 2013, 181-189

[9]. Bello-Imam, I. B., Oshinebo, B. O., \& Ojeifo, S. A. Fundamental of human resorce management in nigeria (Nigeria: College Press and Publisher Limited, 2007).

[10]. Geet, S. D., Deshpande, A. D., \& Deshpande, A. A. Human resource management (1st ed. Nirali Prakashan, 2009).

[11]. Byars, L. L., \& Rue, L. W. Human reource management (New York: McGraw-Hill, 2000).

[12]. Cole, G. A. Personnel and human resource management (London: Thompson, 2002).

[13]. Obikoya, J. The foundations of human resource management (1st ed. Ijebu-Ode Nigeria: Pius Debo Press, 2002).

[14]. French, W. Human rsource management (6th ed. Boston: Hougston Miffin Co, 2006).

[15]. Gungor, P. The Relationship between Reward Management Sstem and Procedural, Social and behavioural Sciences, 10(3), 2011, 1510-1520.

[16]. Obikoya, J. Essentials of personnel management (1st ed. Ijebu-Ode Nigeria: Pius Debo Press, 1996).

[17]. Heathfield, S. M. Training: your investment on people development and retention. Retrieved from About.com Guide http://humanresource.about.com/od/educationgeneral/a/training_invest.htm, 2012, January 20).

[18]. Ivancevich, J. M. Human resource management (8th ed. Boston: Irwin McGraw-Hill, 2010).

[19]. Falola, H. O., Osibanjo, A. O., \& Ojo, S. I. Effectiveness of training and development on employees' performance and organisation competitiveness in the nigerian banking industry, Bulletin of the Transilvania University of Brasov Series V: Economic Sciences, 7(56), 2014, 160-169.

[20]. Abdul hammed, A. Employee development and its effect on employee performance a conceptual framework. International Journal of Business and Social Science, 2(13), 2011, 224-229.

[21]. Osibanjo, A. O., Salau, O. P., \& Falola, H. O. Modelling the relationship between motivating factors; employee's retention and job satisfaction in the nigerian banking industry, Journal of management Policies and Practices, 2(2), 2014, 63-83.

[22]. Porter, L. W., Bigley, G. A., \& Steers, R. M. motivation and work behaviour (7th ed. New York: McGraw-Hill, 2003)

[23]. Buchanan, D., \& Huczynski, A. Organizational behaviour (3rd ed., Prentice Hall, 1997).

[24]. Yamane, Y. Statistics: An introducory analysis (2nd ed., New York: Harper and Row, 1967). 